\title{
Difficulties in Management of Occupational Exposure in Our Country: A Case Report
}

\section{Ülkemizde Mesleksel Maruziyet Durumunun Yönetilmesinde Yaşanan Güçlükler: Bir Olgu Sunumu}

\author{
Serkan YILMAZ, Murat PEKDEMIR, Elif YAKA \\ Department of Emergency Medicine, Kocaeli University Faculty of Medicine, Kocaeli, Turkey
}

\begin{abstract}
SUMMARY
Occupational exposure to hazardous materials is a serious problem in developing countries. Unfortunately, the different presentations result in nonspecific clinical syndromes, making diagnosis difficult. We discuss lessons learned during the assessment and treatment of occupational exposure in two industrial workers. Two employees of a facility that manufactures plastic floor covering were admitted to the emergency department with complaints including inability to ambulate, lethargy and dizziness. It was thought that the patients' neurological symptoms resulted from toxic encephalitis and refractory hypokalemia due to renal medullary damage. No material safety data sheets were available for consultation, and the authorities at the manufacturing facility were unable to provide reliable information about the material involved. On-site exposure evaluation was not performed and these conditions made the exact etiology of the patients' condition unclear. It was thought that toluene, which was used as a solvent during the manufacture of vinyl fluoride, could be responsible for the existing clinical condition. Both patients were treated symptomatically and discharged with minor cognitive impairment, which was assessed during follow-up. Various difficulties were experienced during the management of patients suffered from occupational exposure. Material safety data sheets for industrial chemicals should be available at manufacturing plants. On-site exposure evaluation would be useful for more accurate assessment of exposed patients.
\end{abstract}

Key words: Emergency treatment; occupational exposure; toluene.

\section{ÖZET}

Mesleki maruziyet gelişmekte olan ülkelerde, ciddi ancak yeterince kayıtlara geçirilememiş bir sorundur. Sıklıkla nonspesifik semptomlarla başvuran bu hastaların tanı ve tedavisinde birçok güçlük yaşanmaktadır. Bu makale, bir mesleki maruziyet vakasının değerlendirmesi sırasında elde edilen deneyimlerin paylaşılması amacıyla hazırlanmıştır. Plastik yer döşemeleri üretiminde çalışan iki işçi yürüyememe, uyuşukluk ve baş dönmesi, bilinç bulanıklığı gibi yakınmalarla acil servise başvurdu. Her iki hastada da nörolojik semptomlara yol açan toksik ensefalit ve dirençli hipokalemiye yol açan renal medüller hasar düşünüldü. Gerek fabrikada kullanılan maddelere dair kayıtlara ulaşılamaması ve fabrika yetkilerinden bilgi alınamaması, gerekse hızlı bir şekilde olay yeri toksikolojik değerlendirmesinin yapılmaması nedeniyle etyolojiye kesin olarak karar verilemedi. Fabrikada çözücü olarak kullanılan toluenin klinik tablodan sorumlu olabileceği düşünüldü. Şüpheli kimyasal ajanlara maruz kalma nedeniyle başvuran hastaların değerlendirilmesi sırasında birçok güçlük yaşanmaktadır. Sanayide kullanılan kimyasallar ile ilgili bilgilerin ulaşılabilir olması, bu konuda ulusal bir veritabanı hazırlanması, toksikolojik olay yeri değerlendirmesinin hızlı ve etkin şekilde yapılması bu hastalarının doğru değerlendirilebilmelerine yardımcı olacaktır.

Anahtar sözcükler: Acil tedavi; mesleksel temas; toluen.

Submitted (Geliş tarihi): July 9, 2011 Accepted (Kabul tarihi): January 19, 2012 Published online (Online baskı): March 5, 2012 Correspondence (İletişim): Serkan Yılmaz, M.D. Kocaeli Üniversitesi Tıp Fakültesi Hastanesi, Acil Tıp Anabilim Dalı, 41380 Kocaeli, Turkey e-mail (e-posta): mdserkan@hotmail.com 


\section{Introduction}

Occupational exposure is a serious but poorly documented problem, especially in developing countries. Unfortunately, the different presentations result in nonspecific clinical syndromes that make diagnosis difficult. We discuss the lessons learned during the assessment and treatment of occupational exposure in two industrial workers.

\section{Case Report}

Two males (aged 39 and 34 years) employed a plastic floor cover manufacturing facility were admitted to the emergency department (ED). Both complained of generalized weakness, leg-muscle cramps, inability to ambulate, lethargy, and dizziness. They were placed in an isolation room following admittance.

The patients had been employed at the factory for 13 and 11 years, respectively, which mainly produces vinyl fluoride. It was found that no similar event had previously occurred to any of the patients at the plant and none of those patients had a medical history relevant to the current complaints.

Initial evaluation indicated that the patients were not fully oriented or cooperative, and had slurred speech. Vital signs were within normal limits (first patient: heart rate 74 bpm, respiratory rate 18 , blood pressure $119 / 65 \mathrm{mmHg}$, temperature $36.7^{\circ} \mathrm{C}$, and oxygen saturation $99 \%$ on room air; second patient: heart rate $82 \mathrm{bpm}$, respiratory rate 17 , blood pressure $127 / 72 \mathrm{mmHg}$, temperature $36.4^{\circ} \mathrm{C}$, and oxygen saturation $98 \%$ on room air). Motor and sensory examination, reflexes, and cerebellar functions were also normal. All other systemic examination results were normal.

Initial laboratory examination revealed hypokalemia $\left(\mathrm{K}^{+}=\right.$ $1.9 \mathrm{mEq} / \mathrm{l}$ and $2.1 \mathrm{mEq} / \mathrm{l}$ ) and mild metabolic acidosis (arterial blood gasses: $\mathrm{pH}=7.32, \mathrm{pCO}_{2}=43, \mathrm{pO}_{2}=64, \mathrm{HCO}_{3}{ }^{-}=18$, $\mathrm{AG}=16, \mathrm{SO}_{2}=99 \%$ for the first patient; $\mathrm{pH}=7.30, \mathrm{pCO}_{2}=44$, $\mathrm{pO}_{2}=61, \mathrm{HCO}_{3}^{-}=15, \mathrm{AG}=18, \mathrm{SO}_{2}=98 \%$ for the second). The ECGs were normal. Toxic drug screening for tetrahydrocannabinol, amphetamines, methamphetamines, barbiturates, benzodiazepines, cocaine, opiates, tricyclic antidepressants, phencyclidine, and methadone was negative.

The patients remained clinically stable and underwent cranial computed tomography (CT), which was interpreted as normal. Magnetic resonance imaging (MRI) with turbo spin echo (TSE) T2-weighted and FLAIR (fluid attenuated inversion recovery) images showed damage to white matter structures and subcortical regions.

The apparently lipid-dependent distribution of MRI images appeared to correlate with the common symptoms and signs of industrial exposure to an organic neurotoxic such as toluene, benzene, or xylene. Based on the history of the industrial plant, the presence of more than one affected patient, and laboratory and MRI results, it was thought that toxic encephalitis might be responsible for the neurologic symptoms; and that renal tubular damage might be responsible for the hypokalemia and mild acidosis following industrial exposure. No information on the exposure agents was available to confirm our diagnosis. The patients were hospitalized with conservative therapy comprising supplemental oxygen, $\mathrm{KCl}$ infusion for four days at a rate of $100 \mathrm{mEq} /$ day, and sodium bicarbonate $5 \mathrm{mEq} / \mathrm{kg}$ IV infusion over 8 hours for two days.

The symptoms improved after the third day. Hypokalemia and metabolic acidosis were completely resolved at the end of the fourth day. Both patients were discharged from the hospital six days after the admission. On follow-up one month later, both patients showed slight cognitive abnormalities presented with minimal attention and memory deficit.

\section{Discussion}

Disorientation, lethargy hypokalemia, and metabolic acidosis were present in our patients. This prompted us to think that toluene, which was used in the plant, may have been responsible for the existing clinical condition. We also concluded that toxic encephalitis resulted in the patients' neurological symptoms; and that renal tubular damage caused hypokalemia and mild acidosis.

Toluene (methylbenzene, toluol, phenylmethane) is an aromatic hydrocarbon $\left(\mathrm{C}_{7} \mathrm{H}_{8}\right)$ commonly used as an industrial solvent in paints, coatings, thinners, inks, detergents, pharmaceuticals, etc. It can be released in trace amounts from some plastics. ${ }^{[1]}$ Toluene is found in gasoline, acrylic paints, varnishes, lacquers, paint thinners, adhesives, glues, rubber cement, airplane glue, and shoe polish. At room temperature, it is a colorless, sweet-smelling, and volatile liquid. The principal effect of toluene exposure is central nervous system (CNS) depression including euphoria, hallucinations, delusions, tinnitus, dizziness, confusion, headache, vertigo, seizures, ataxia, stupor, and coma. ${ }^{[2]}$ Toluene has direct negative effects on cardiac automaticity and conduction, and can sensitize the myocardium to circulating catecholamines. Pulmonary effects include bronchospasm, asphyxia, acute lung injury (ALI), and aspiration pneumonitis. Toluene can affect skeletal muscles directly, resulting in rhabdomyolysis and myoglobinemia. Metabolic acidosis, hypokalemia, hematuria, proteinuria, distal renal-tubular acidosis, and pyuria have been reported in chronic toluene toxicity, although these effects have usually been reversible. ${ }^{[3]}$ Patients with acute toluene poisoning may present with a range of pulmonary 
and CNS symptoms depending on duration and route of exposure, and the level of toluene in the air or liquid.

Toxicological risk assessment should be routinely performed following exposure to a chemical agent. Questions in cases of occupational exposure include: Which agent was a person exposed to? What are the likely problems in the treatment of such patients? What is the prognosis? Are there additional problems concerning other workers at the facility and potentially affecting hospital staff? In case of exposure to toxic materials, site investigation is of great importance to determine the characteristics of the event, protection measures, and decontamination methods. If hazardous materials response-teams have conducted reconnaissance, atmospheric monitoring, or field environmental testing, these data and any actual or presumptive identification of the toxicant involved, can assist in subsequent clinical decision making. ${ }^{[4]}$

In order to identify the agent involved, appropriate and reliable information should be widely available. In the USA, systems such as the Occupational Safety and Health Administration's (OSHA) Hazard Communication Standards allow open access to data on industrial chemicals. ${ }^{[5]}$ It is recommended that developing countries should also implement national databases on where chemicals are used, intoxication indicators, and appropriate protection and decontamination procedures. Like most other developing countries, there is no such database in place in Turkey and physicians treating exposure patients may be unable to access muchneeded information from reliable sources during emergency patient care.

In Turkey, an on-site assessment, toxicological risk assessment, and evaluation of employee health and workplace safety is the only way to ensure judicial authority. In our cases, the forensic authorities were informed of the difficulties in obtaining information from reliable sources, in the hope of initiating an investigation to resolve this issue. Unfortunately, since such investigations would require several days to complete, they provide no help in the assessment of patients in emergency situations.

\section{Conclusion}

Occupational exposure to industrial agents should be considered in patients who work in industries producing paints, coatings, thinners, inks, detergents, and pharmaceutical agents; and who present with complaints such as weakness, altered mental status, or pulmonary and cardiac signs and symptoms. Tools such as "Toxicological Risk Assessment" should be implemented in developing countries to assist effective ED management of exposure patients.

\section{Conflict of Interest}

The author(s) declare(s) no conflict of interest related to this work.

\section{References}

1. McKeown NJ, Slapper D, VanDE Voort JT et al. Toxicity Toluene. Available at : http://www.emedicine.com/emerg/topic818939.htm (Accessed: September 11, 2011).

2. Occupational Healt Guideline for Toluene. Available at: http:// www.cdc.gov/niosh/docs/81-123/pdfs/0619.pdf (Accessed December 10, 2011).

3. Case Studies in Environmental Medicine (CSEM): Toluene Toxicity. Available at: http://www.atsdr.cdc.gov/HEC/CSEM/toluene/docs/toluene.pdf (Accessed Sep 4 2011).

4. Burgess JL, Keifer MC, Barnhart S, Richardson M, Robertson WO. Hazardous materials exposure information service: development, analysis, and medical implications. Ann Emerg Med 1997;29:248-54.

5. OSHA. 2000 (Revised). Hazard Communication Guidelines for Compliance. OSHA 3111. Available at: http://www.osha.gov/ Publications/osha3111.pdf (Accessed Oct 29 2011). 